\title{
Kritiese Beoordeling van Evaluasietegnieke van toepassing op Gesplete-lip-en-verhemelte-babas
}

\author{
Brenda Louw, D.Phil (Pretoria) \\ Isabel C. Uys, D.Phil (Pretoria) \\ Departement Spraakheelkunde en Oudiologie, \\ Universiteit van Pretoria, Pretoria.
}

\section{OPSOMMING}

Die verkryging van 'n klinies geldige en 'n voorskrywende profiel van 'n baba se kommunikasiefunksionering verg noukeurige seleksie van ondersoekmetodes en meetinstrumente wat aangewendword. Voorgestelde evaluasietegnieke wat van toepassing is op swart gesplete-lip-enverhemelte-babas word teen die agtergrond van 'n kritiese oorsig van die evaluasieproses beoordeel in terme van navorsings- en kliniese toepassingswaarde. Vyf-en-twintig swart babas met gesplete verhemelte onder die ouderdom van twaalf maande het as proefpersone gedien. Riglyne vir toepassing van die voorgestelde evaluasiemodel deur middel van direkte dienslewering deur die spraakterapeut en deur middel van konsultasie-as-voorkoming in 'n multi-kulturele gemeenskap word verskaf.

\section{ABSTRACT}

The obtaining of a clinically valid and prescriptive profile of the communication function of infants calls for an accurate selection of the research methods and measuring instruments to be used. Suggested evaluation techniques applicable to black cleft lip and palate infants are judged and evaluated within the framework of a critical review of the evaluation process in terms of research and clinical applicability. Twenty-five black cleft lip and palate infants under the age of twelve months served as subjects. Guidelines are supplied for use of these techniques through direct services provided by the speech pathologist and through consultation - as - prevention in a multi-cultural society. 
Die term 'diagnose' verwys na 'n deeglike begrip van 'n probleem en dit word verkry deur evaluering. Die evalueringsproses sluit waarneming, meting, beskrywing en differensiasie in (Emerick \& Haynes, 1986) en dit dien as ' $n$ basis vir behandeling. Gevolglik bepaal die kwaliteit van die evaluering in 'n groot mate die effektiwiteit van behandeling.

In die evalueringsproses word gebruik gemaak van objektiewe, gestandaardiseerde metingstegnieke of toetse, sowel as sensitiewe, doelgerigte subjektiewe waarneming waarvolgens diagnostiese data ingesamel word. Formele toetse is hoofsaaklik gerig op die identifikasie van 'n problcem, maar verskaf dikwels nie genoeg inligting oor die aard van die probleem en doelwitte vir behandeling nie. Toetse verskerp die diagnostikus se waarnemingsvaardighede en verskaf leidrade vir verdere verkenning en intervensie. Hoe meer bewus die diagnostikus word van die kompleksiteit van menslike kommunikasie, hoe meer verloor die toetse wat gebruik word geloof waardigheid. Die vaardige diagnostikus beskou nie toetstellings as ' $n$ doel op sigself nie, maar eerder as aspekte van die mens se kommunikasievaardigheid (Emerick \& Haynes, 1986). Daar is dus plek vir beide objektiewe en subjektiewe evaluasies in 'n omvattende, maar ook intensiewe diagnostiese program.

Verder moet diagnostiese programme voldoen aan sekere kriteria. Evaluering berus op sekere basiese teoretiese veronderstellings of modelle. Dit moet die ouderdom, kultuur en sosioekonomiese status van die populasie in ag neem omdat betroubaarheid en geldigheid nie slegs 'n funksie van die toets self is nie, maar ook van die groep waarop dit toegepas word (Schepers, 1972). Die kwantiteit van inligting wat in verband met behandeling verskaf word en die verskillende aspekte wat ondersoek word, is ook faktore waaraan die effektiwiteit van diagnose gemeet kan word.

Hierdie faktore moet dus ook in ag geneem word by evaluering van babas wat ' $n$ risiko vertoon om ' $n$ kommunikasie-afwyking te ontwikkel. Swart gesplete-lip-en-verhemelte-babas vorm so 'n groep, maar omdat die gebied nog nie werklik die aandag van navorsers geniet het nie, bestaan daar geen beproefde diagnostiese battery vir evaluering van hierdie groep se kommunikasie nie (Louw, 1986).

Met'die bogenoemde kriteria as uitgangspunt is daar gepoog om 'n werkbare diagnostiese battery! bestaande uit verskeie evaluasietegnieke, van toepassing op swart gesplete-lip-en-verhemeltebabas, saam te stel. 'n Holistiese evaluasiemodel, met in agneming van die sinergistiese aard van ontwikkelingsareas, is as teoretiese grondslag ontwikkel (Louw, 1986). Hierdie model berus dus op die beginsel dat die geheel meer as die som van die dele is. Soos uit Figuur 1 blyk, verkry die diagnóstikus reeds uit hierdie teoretiese oriëntasie 'n aanduiding van die omvang van evaluasieareas.

Hierdie teoretiese veronderstelling laat ook ruimte vir inagneming van die ander kriteria waarvolgens die effektiwiteit van evaluasietegnieke beoordeel word, oa die eiesoortige aard van die toetspopulasie, die verskaffing van inligting vir intervensie en 'n breë omvang van aspekte wat ondersoek behoort te word. So byvoorbeeld word die evaluering van beide die orofasiale morfologie en vroeë gedragsontwikkeling vereis indien daar 'n verteenwoordigende beeld van die manifestasie van die afwyking in die baba voorgehou moet word. Tydens evaluering moet die interaksie wat tussen die baba se orofasiale morfologie en kommunikasievermoëns voorkom dus tesame met 'n beskouing van vroeë kommunikasiegedrag binne die raamwerk van algemene ontwikkeling bepaal word. Vroeë ontwikkeling word gekenmerk deur 'n simbiotiese interaksie wat tussen ver-

Die Suid-Afrikaanse Tydskrif vir Kommunikasieafwykings, Vol. 33, 1986

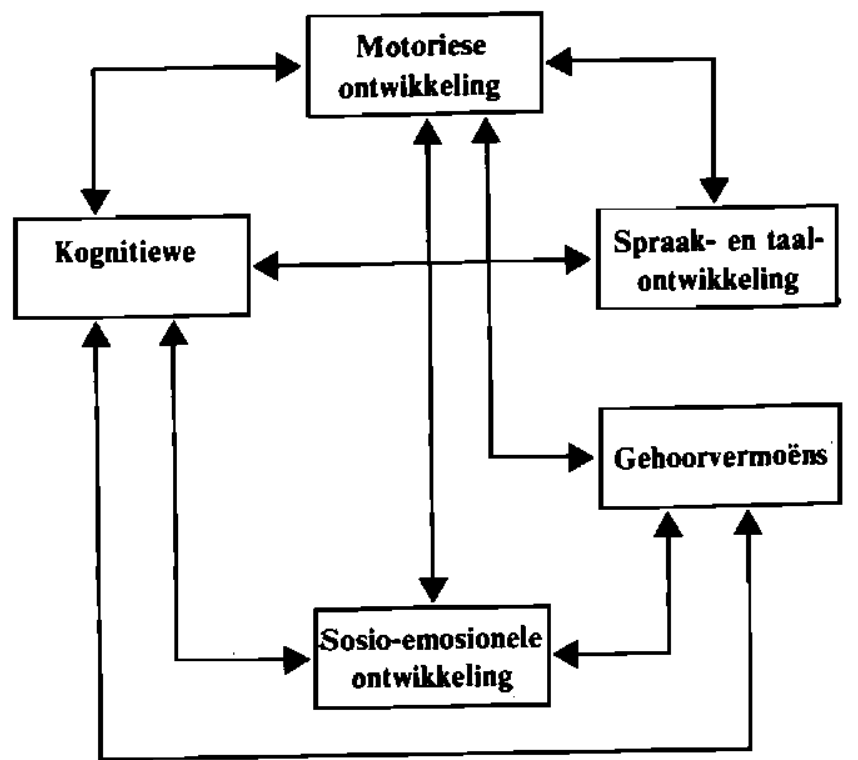

Figuur 1: Skematiese voorstelling van die sinergistiese aard van ontwikkelingsareas waarop die holistiese evaluasiemodel berus

skillende ontwikkelingsareas bestaan en hierdie sinergistiese aard van ontwikkeling moet geëvalueer word om 'n verteenwoordigende beeld van die baba se algemene funksionering te verkry.

Die doel van hierdie artikel is om die geselekteerde evaluasietegnieke, van toepassing op swart gesplete-lip-en-verhemeltebabas, krities te beoordeel in terme van navorsings- en kliniese effektiwiteit.

\section{METODOLOGIE}

Die verkryging van 'n klinies geldige en voorskrywende profiel van 'n baba se kommunikasiefunksionering verg noukeurige seleksie van ondersoekmetodes en meetinstrumente wat aangewend word. Volgens McLean \& McLean (1978) moet die doel van evaluering, die aard van die meetinstrument en die metodes van gebruik van die meetinstrument tydens seleksie daarvan oorweeg word. Vanweë die leemtes en beperkinge van beskikbare meetinstrumente en die individuele kenmerke en behoeftes van babas, is die toepassing van slegs gestandaardiseerde toetse nie voldoende vir 'n omvattende evaluasie nie. Nie-gestandaardiseerde evaluasieprosedures kan met groot vrug aangewend word om addisionele data oor vroeë kommunikasiefunksionering te verskaf. Riglyne vir uitvoering wat in die literatuur verskaf word, verhef nie-gestandaardiseerde evaluasieprosedures bo toevallige en informele waarnemings (McLean \& McLean, 1978).

In die lig van die voorafgaande teoretiese agtergrond is 'n evaluasiemodel wat op swart babas met gesplete lip en verhemelte van toepassing is, ontwikkel en empiries ondersoek.

\section{MATERIAAL EN APPARAAT}

Die holistiese evaluasiemodel van toepassing op swart babas met gesplete lip en verhemelte is aangewend en word in Tabel 1 omskryf in terme van evaluasieareas, materiaal en apparaat en die evaluasiewyses wat benut word.

Die motivering vir die seleksie van die evaluasiewyses gegrond op die evaluasiemodel word vervolgens bespreek. 
Tabel 1: Opsommende weergawe van die bolistiese evaluasiemodel vir babas met gesplete lip en verhemelte

\begin{tabular}{|c|c|c|}
\hline Evaluasiearea & Materiaal en apparaat & Evaluasiewyse \\
\hline Orofasiale morfologie & Siemens Somatom 2 heelliggaamskandeerder & $\begin{array}{l}\text { Uitvoering van: } \\
\text { Gerekenariseerde tomografie }\end{array}$ \\
\hline Kognitiewe ontwikkeling & $\begin{array}{l}\text { Cognitive-Social Communication } \\
\text { Assessment (Dunst, 1978) } \\
\text { Developmental Assessment Schema: } \\
\text { :Perceptuo-Cognitive Skills Subscale } \\
\text { (Anderson, Nelson \& Fowler, 1978) } \\
\text { Birth to Three Developmental Scale: } \\
\text { Problem Solving Subscale (Bangs \& } \\
\text { Dodson, 1979) }\end{array}$ & Toepassing van evaluasieskale \\
\hline Gehoorvermoëns & $\begin{array}{l}\text { Amplaid Reactometer (Amplied USA Inc). } \\
\text { Grayson-Stadler, } 1723 \text { Middle Ear Analyzer } \\
\text { (GSI 27). }\end{array}$ & $\begin{array}{l}\text { Uitvoering van: } \\
\text { Elektro-akoestiese impedansoudiometrie } \\
\text { (Hodgson, 1980) } \\
\text { Vryeveld pedo-oudiometriese toetsing } \\
\text { (Martin, 1978) }\end{array}$ \\
\hline $\begin{array}{l}\text { Kommunikaisevermoëns } \\
\text { - Voedingsproses }\end{array}$ & $\begin{array}{l}\text { Vorm vir die optekening van data versamel en } \\
\text { waarnemings gemaak. }\end{array}$ & $\begin{array}{l}\text { Data-insameling deur middel van: } \\
\text { - raadpleging van bedkaarte in hospitaallêer, } \\
\text { - konsultasies met saalsuster/moeder/ } \\
\text { oppasser, } \\
\text { - direkte waarneming van voedingsessie. } \\
\text { Optekening van bogenoemde inligting op 'n } \\
\text { opgestelde vorm. }\end{array}$ \\
\hline Huilgedrag & $\begin{array}{l}\text { Elastiese rekkie vir indusering van } \\
\text { pynstimulus (Michelsson et al., 1982) } \\
\text { Nakamichi 550-bandopnemer met } \\
\text { TDK SA-X90-klankkassette. } \\
\text { Voice Identification } 700 \text { Series - } \\
\text { spektrograaf. }\end{array}$ & $\begin{array}{l}\text { Ontlokking en spektrografiese ontleding van } \\
\text { pyngeïnduseerde huilpatrone } \\
\text { Michelsson et al., 1982). }\end{array}$ \\
\hline - Vokaliseringsgedrag & $\begin{array}{l}\text { Babaspeelgoed } \\
\text { Nakamichi 550-bandopnemer met } \\
\text { TDK SA-90-klankkassette } \\
\end{array}$ & $\begin{array}{l}\text { Ontlokking en fonetiese en frekwensie- } \\
\text { ontledings van vokaliseringsgedrag } \\
\text { (Smith \& Oller, 1981). }\end{array}$ \\
\hline $\begin{array}{l}\text { - Reseptiewe en } \\
\text { ekspressiewe } \\
\text { taalvermoëns }\end{array}$ & $\begin{array}{l}\text { Receptive Expressive Emergent Language } \\
\text { Scale (Bzoch \& League, 1971). } \\
\text { Developmental Assessment Schema: } \\
\text { Speech-Language Receptive/Expressive } \\
\text { Subscales (Anderson, Nelson \& Fowler, 1978) } \\
\text { Birth to Three Developmental Scale } \\
\text { Language Comprehension and Expression } \\
\text { Subscales (Bangs \& Dodson, 1979) }\end{array}$ & Toepassing van evaluasieskale \\
\hline $\begin{array}{l}\text { - Kommunikasie- } \\
\text { interaksievermoëns }\end{array}$ & $\begin{array}{l}\text { Cognitive-Social Communication } \\
\text { Assessment (Dunst, 1978) } \\
\text { Nonverbal Indicators of Communication } \\
\text { Exchange (Du Bose-Fewell, 1982) } \\
\text { Vorm vir optekeninge van data versamel } \\
\text { Nakamichi } 550 \text { bandopnemer en TDK } \\
\text { SA-X90-klankkassette }\end{array}$ & $\begin{array}{l}\text { Toepassing van evaluasieskale } \\
\text { Subjektiewe waarneming van moeder-kind } \\
\text { interaksie (Bower, 1977; Trevarthen, 1979; } \\
\text { Kaye, 1980; Owens, 1984; Strydom, 1985) }\end{array}$ \\
\hline $\begin{array}{l}\text { - Motoriese } \\
\text { ontwikkeling }\end{array}$ & $\begin{array}{l}\text { Birth to Three Developmental Scale: } \\
\text { Motor Subscale (Bangs \& Dodson, 1979). } \\
\text { Developmental Assessment Schema; Gross } \\
\text { and Fine Motor Subscales (Anderson, } \\
\text { Nelson \& Fowler, 1978). }\end{array}$ & Toepassing van evaluasieskale \\
\hline
\end{tabular}

Nelson \& Fowler, 1978).

- Gerekenariseerde tomografie. Hierdie tegniek is geselekteer om die orofasiale morfologie van babas te bestudeer vanweë die feit dat die pasiënt aan minimale bestraling blootgestel word; waarneming van beide harde- en sagte- weefseldetail moontlik is; morfologiese verhoudings sonder versteurings deur die ondersoekprosedure bestudeer kan word; en 'n driedimensionele beeld van strukture verkry word wat morfologiese detail visualiseer en deur 
geen ander radiologiese tegnieke geëwenaar word nie (Dickson en Maue-Dickson, 1983; Banna, 1976). Hierdie tegniek is sover slegs vir navorsing met gesplete-lip-enverhemelte-babas aangewend en die praktiese uitvoerbaarheid as roetinemeetinstrument by hierdie babas is tot dusver nie bepaal nie. Ten spyte hiervan hou die tegniek talle voordele bo ander radiologiese tegnieke in en is dit geselekteer spesifiek met die doel om omvattende driedimensionele data van die orofasiale morfologie te verskaf.

- Vryeveldtoetsing en elektro-akoestiese impedanstoetsing. Hierdie twee tegnieke is geselekteer as geskikte metodes om die gehoordrempels en middeloorfunksionering van babas te bepaal.

Vryeveldtoetsing is 'n standaardprosedure in pedo-oudiometriese toetsing en word suksesvol aangewend om babas se reaksie op klank te evalueer (Hodgson, 1980). Hierdie tegniek is ook bewys om lae vals-positiewe resultate in grootskaalse ondersoeke te vertoon en word as 'n effektiewe wyse van gehoorsifting aanvaar (Katz, 1978).

Impedansoudiometrie beskik oor sekere kenmerke en voordele wat hierdie tegniek vir toepassing op kinders geskik maak, naamlik: dit is 'n objektiewe kwantitatiewe metode wai vinnig en effektief uitgevoer kan word; dit is akkuraat en verg geen aktiewe deelname of konsentrasie van die kind nie, en word nie beïnvloed deur 'n hoë peil van omgewingsgeraas nie (Hodgson, 1980)

- Ontwikkelingskale. Kognitiewe en motoriese ontwikkeling word dikwels tesame met taalvermoëns en kommunikasieinteraksievermoëns deur middel van vroeë ontwikkelingskale geëvalueer. Gevolglik word die evaluering van hierdie vier gedragsareas saam in terme van die geselekteerde meetinstrumente bespreek.

Meetinstrumente is geselekteer uit die beskikbare ondersoekmetodes wat op vroeë kommunikasiegedrag fokus (Louw, 1986). Die meeste van hierdie meetinstrumente is normgerig, globaal en verskaf oppervlakkige eerder; as diepte-inligting oor ontwikkeling. Gevolglik word daar nie aan al die teoretiese kriteria vir 'n toepaslike meetinstrument voldoen nie. 'n Tweede probleem wat ondervind is, is dat slegs in beperkte verskeidenheid van hierdie meetinstrumente in Suid-Afrika beskikbaar is. Dit word toegeskryf aan die feit dat levaluering van prelinguistiese vaardighede 'n relatief resente konsep is en dat meeste van die meetinstrumente in die VSA saámgestel en gepubliseer is.

Die Receptive Expressive Emergent Language Scale (REEL) (Bzoch \& League, 1971); Birth to Three Developmental Scale (Bangs \& Dodson, 1979) en die Non-Verbal Indicators of Communicative Exchange (NICE) (Du Bose-Fewell, 1982) is geselekteer omdat hulle gestandaardiseerde meetinstrumente vir die evaluering van vroeë ontwikkeling en kommunikasieontwikkeling van babas is.

Prosedures, materiaal, apparaat en die bepuntingsprosedure word gespesifiseer om betroubare, geldige en objektiewe data te verskaf (McLean \& McLean, 1978). Die Developmental Assessment Schema (DAS) (Anderson, Nelson \& Fowler, 1978); die Cognitive-Social Communication Assessment (CSCA) (Dunst, 1978) en die subjektiewe waarneming van moeder-kind-interaksie (Trevarthen, 1979; Kaye, 1980; Strydom, 1985) is ook geselekteer as betroubare meetinstrumente vir die evaluering van vroeë ontwikkeling en kommunikasie-ontwikkeling. Laasgenoemde is nie-gestandaardiseerde evaluasieprosedures met sistematiese voorskrifte vir toepassing om ' $n$ redelike mate van objektiwiteit te verseker. Kombinering van hierdie twee tipes evaluasiewyses laat toe vir die bepaling van die chronologiese ouderdomsvlak waarop die baba funksioneer sowel as vir die inherente implikasie dat genoegsame data verskaf word vir gedetailleerde beplanning van behandeling (Liebergott et al. 1984). Vanweë die ooreenstemmende wyses van data-insameling, naamlik direkte waarneming van gedrag en onderhoudsvoering met ouers, vul hierdie ontwikkelingskale mekaar goed aan (McLean \& McLean, 1978; McClowry, 1982). Sodoende word daar ook toegelaat vir die evaluering van 'n wye omvang van gedrag wat akkurate bepaling van die vlak van funksionering moontlik maak. Toepassing van hierdie toetsbattery laat toe vir die kategorisering van kommunikasie en aanverwante gedrag. Gevolglik kan verbande tussen die verskillende ontwikkelingsareas bepaal word tesame met die beskrywing van die baba se individuele patroon van ontwikkeling.

- Evaluasieprotokol: Voedingsproses. 'n Prosedure vir datainsameling oor die voedingsproses is deur Louw (1986) opgestel vanweë die gebrek aan so'n evaluasieprotokol in die literatuur. Die doel van die evaluering van die voedingsproses is slegs om te bepaal hoe funksie daar uitsien en dus is data deur middel van die raadpleging van lêerinligting, konsultasie met sorggewendes en direkte waarneming van voedingsessies ingesamel (Louw, 1986). Objektiewe meetinstrumente soos video- en kineradiografiese opnames is nie uitgevoer nie aangesien 'n diepteversameling van fisiologiese data nie binne die grens van hierdie evaluasiemodel val nie.

- Speksrografiese analise van huilgedrag. Vir die bestudering van huilgedrag is die toediening van 'n pynstimulus om gedrag te ontlok en die spektrografiese analise van bandopnames as evaluasiemetodes geselekteer (Michelsson et al. 1982).

Ontlokking van huilgedrag deur die toediening van 'n pynstimulus is bo die bestudering van spontane huilgedrag geselekteer om gedifferensieerde huilpatrone uit te skakel (Michelsson et al. 1982). Die toediening van 'n pynstimulus laat toe vir die maak van objektiewe en gekontroleerde vergelykings op 'n inter- en intrapersoonlike vlak. Hierdie metode word deur verskeie navorsers gekritiseer maar is steeds die mees algemene ontlokkingswyse vir die bestudering van huilpatrone wat in die literatuur aangetref word (Crystal, 1973; Prescott, 1980).

- Fonetiese onsleding van vokaliseringsgedrag. Die evaluasiewyse wat vir die bestudering van vokaliseringsgedrag geselekteer is, is ook volgens literatuuraanbevelings bepaal. Vokaliseringsgedrag is in 'n natuurlike konteks ontlok en met behulp van oudio-bandopnames volgens die prosedures wat in die literatuur beskryf word, foneties ontleed (Smith \& Oller, 1981; O'Gara \& Logemann, 1983).

Uit voorafgaande bespreking blyk dit dus dat ' $n$ verskeidenheid evaluasiemetodes en meetinstrumente voorgestel is. Die navorsings- en kliniese effektiwiteit en bruikbaarheid van die geselekteerde evaluasietegnieke kan egter slegs deur empiriese toepassing op 'n omskrewe populasie beoordeel word.

\section{PROEFPERSONE}

Vyf-en twintig swart babas met onherstelde gesplete lip en verhemelte is tydens hulle hospitalisering in die Ga-Rankuwa Hospitaal as proefpersone geselekteer. Die proefpersone se ouderdomme strek van 0,7 maande tot 11,2 maande met ' $n$ gemiddelde ouderdom van 5,95 maande. Die groep vertoon 'n byna gelyke verspreiding wat hul geslag betref, daar is naamlik 13 
seuns en 12 dogters. Die 25 proefpersone is afkomstig uit huise wat 'n verskeidenheid van 9 tale as huistale het, naamlik Venda, Noord-Sotho, Suid-Sotho, Zulu, Swazi, Shangane, Xhosa, Tswana en Ndebele.

Vyf tipes gesplete lip en verhemelte is deur die proefpersone gemanifesteer. Numeriese waardes is aan die verskillende tipe splete toegeken om die graad van die afwyking aan te dui. Die klassifikasiesisteem wat deur die American Cleft Palate Association (ACPA) voorgehou word, is gevolg (Berlin, 1979; McWilliams et al. 1984). Die verspreiding van die proefpersone na aanleiding van die graad van die afwyking word in Tabel 2 verskaf. Die belangrikste eienskappe van die proefpersone word opsommend in Tabel 3 weergegee.

Tabel 2: Graad van gesplete lip en verhemelte van proefpersone

\begin{tabular}{|l|c|c|}
\hline \multicolumn{1}{|c|}{$\begin{array}{c}\text { Kategorie van tipe spleet } \\
\text { (ACPA-klassifikasie) }\end{array}$} & $\begin{array}{c}\text { Waarde } \\
\text { toegeken }\end{array}$ & $\begin{array}{c}\text { Getal } \\
\text { proefpersone }\end{array}$ \\
\hline $\begin{array}{l}\text { Spleet van die lip en alveolus } \\
\text { Spleet van die velum }\end{array}$ & 1 & 6 \\
Spleet van die palatum en velum & 3 & 3 \\
Unilaterale spleet van die lip, & & 2 \\
alveolus, palatum en velum & 4 & 9 \\
Bilaterale spleet van die lip, & & 5 \\
alveolus, palatum en velum & 5 & \\
\hline
\end{tabular}

Tabel 3: Opsommende weergawe van die belangrikse kenmerke van die proefpersone

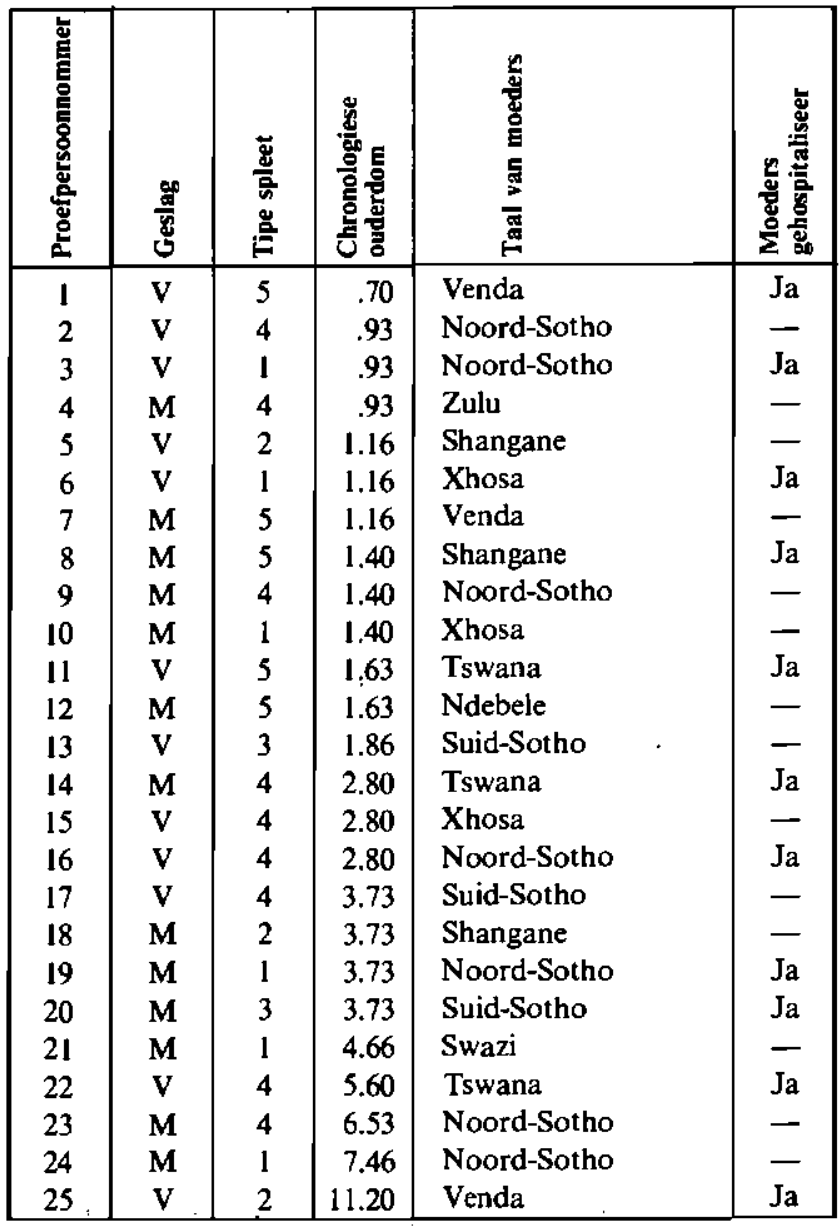

\section{PROSEDURE}

Elk van die $\mathbf{2 5}$ proefpersone is binne een week na opname in die Ga-Rankuwa Hospitaal individueel geëvalueer. Vyf datainsamelingsessies is vir elke proefpersoon geskeduleer. Een sessie is aan die uitvoering van gerekenariseerde tomografie gewy.
Hierna is een sessie vir gehoortoetsing, insameling van data oor die voedingsproses en die ontlokking van huilgedrag benut. In die twee daaropvolgende sessies is kognitiewe, motoriese, sosioemosionele en taalontwikkeling geëvalueer. 'n Sessie is hiema afgestaan aan die ontlokking van vokaliseringsgedràg en die evaluering van moeder-kind-kommunikasie-interaksie by die proefpersone waar moeders wel beskikbaar was vir die waarneming van interaksie met hulle babas.

Die evaluasieprosedures wat tydens die ontwerp van die evaluasiemodel ontwikkel is, is vir die insameling, optekening en analisering van data in elk van die evaluasieareas aangewend (Louw, 1986).

Die data wat ingesamel is, berus op twee verwerkingsprosedures, naamlik 'n telling (gehoorvermoëns, motoriese, kognitiewe en kommunikasie-ontwikkeling) en 'n meting (afmeting van die orofasiale strukture en metings van huilkenmerke).

Gegewens wat op tellings berus, is deur middel van statistiese metodes verwerk (Louw, 1986). Eerstens is korrelasies bereken om te bepaal watter verwantskappe daar tussen die evaluasieareas bestaan. Tweedens is die voorspellingswaarde van die verskillende ontwikkelingsaspekte wat ten opsigte van mekaar geëvalueer is, statisties bepaal (Louw, 1986).

\section{RESULTATE EN BESPREKING}

In samehang met die doel van die artikel, naamlik die kritiese beoordeling van die evaluasiemetodes en meetinstrumente wat aangewend is, word die resultate soos volg aangebied:

- Resultate wat deur die toepassing van die verskillende evaluasiemetodes en meetinstrumente verkry is.

- Resultate van statistiese berekeninge wat lig werp op die bruikbaarheid van die evaluasiemetodes en meetinstrumente.

Die resultate en bespreking van die evaluasiemetodes word in dieselfde volgorde aangebied as in die seleksie van die evaluasiewyses. (Sien Materiaal en Apparaat.)

\section{- Gerekenariseerde tomografie}

Die orofasiale morfologiese inligting wat verkry:is, is op tweeledige wyse beskryf. Anatomiese landmerke is op die skanderingsfoto's geïdentifiseer en kwalitatiewe beskrywings van die proefpersone se orofasiale morfologie is gemaak. Vanweë verskeie probleme wat met die uitvoering van 'n kwantitatiewe analiseprosedure ondervind is, . is absolute metings met bogenoemde kwalitatiewe beskrywings van waargenome strukture vervang.

Tabel 4 verskaf die anatomiese landmerke wat op die skanderingsfoto's van vyf proefpersone voorkom. Hierdie proefpersone is geselekteer as voorbeelde ter illustrasie van die orofasiale morfologiese inligting wat deur middel van gerekenariseerde tomografie verkry is.

Dit blyk dus volgens Tabel 4 dat ' $n$ verskeidenheid morfologiese strukture op die skanderingsfoto's geïdentifiseer kan word. Relatief min inligting is egter beskikbaar oor die sagte weefsel van die orofasiale strukture wat daarop dui dat die kwaliteit van die skanderingsfoto's steeds nie genoegsaam is om werklik ' $n$ omvattende beskrywing van die orofasiale morfologie van die proefpersone te verskaf nie. Die interpretasie van die skanderingsfoto's volgens die literatuurriglyne wat aangewend is, is bemoeilik deur die feit dat die anatomiese beskrywings in die literatuur gegrond is op die strukture van normale kinders en 
volwassenes wat verskil van die ontwikkelende morfologie van babas.

Tabel 4: Orofasiale morfologiese struktuur wat geidentifiseer is op die skanderingsfoto's van die proefpersone $(n=5)$

\begin{tabular}{|l|c|c|c|c|c|}
\hline Strukture geïdentifiseer & Ppl & Pp4 & Pp9 & Pp17 & Pp23 \\
\hline Nasale septum & + & + & + & + & + \\
Vomerbeen & + & + & + & + & + \\
Nasale holtes & + & + & + & + & + \\
Nasale konga & + & + & + & + & + \\
Sigomatiese boog & + & + & + & + & + \\
Koronoïedproses van die & & & & & \\
mandibula & + & + & + & + & + \\
Mandibulêre kondiele & + & + & + & + & + \\
Mandibulêre ramus & + & + & + & + & + \\
Premaksilla & + & + & + & + & + \\
Maksillêre alveolêre prosesse & + & + & + & + & + \\
Tuberositas van die maksilla & + & - & - & - & - \\
Tong & + & + & - & - & - \\
Nasofarinks & + & + & + & + & + \\
Hamulus & - & - & - & - & + \\
Pterigoïedbeen & + & + & + & + & + \\
Eksterne oorkanaal & - & + & - & - & - \\
Mastoïedproses & - & - & + & - & - \\
Petrusbeen & - & - & + & - & - \\
Oksipitale kondiele & + & + & + & + & + \\
Ordontoïedproses van & & & & & + \\
die aksis & + & + & + & + & + \\
\hline
\end{tabular}

Sleutel: $+=$ waarneembaar

Sleutel: $-=$ nie sigbaar nie

Die kwalitatiewe beskrywing van die skanderingsfoto's is gerig op ' $n$ beskrywing van die invloed wat die tipe spleet op die orofasiale struktuur van die proefpersone uitoefen. Op grond van die beskrywing van die individuele skanderingsfoto's van die proefpersone (Louw, 1986) blyk dit dat die invloed van 'n gesplete lip en verhemelte op die neusstrukture duidelik waarneembaar is. Verskille tussen die spleet-en nie-spleetkante van unilaterale splete is ook duidelik geïllustreer. Die deviasie van die nasale septum en vomerbeen is deurgaans duidelik waarneembaar. Die gebruik van ' $n$ snitdikte van $4 \mathrm{~mm}$ blyk relatief min strukturele detail te verskaf ten opsigte van die palatum en velum, maar is geselekteer om die mate van bestraling te beperk (Banna, 1976). Die tegniek vañ gerekenariseerde tomografie dui egter wel op fyn morfologiesé detail van die proefpersone wat nie anders sigbaar is nie, byvoorbeeld detail oor die benige en kraakbeengedeeltes van die vomer en die hamulus van die mediale pterigoïedplate wat waarneembaar is.

Die gebruik van die tegniek van gerekenariseerde tomografie om inligting aangaande die or ofasiale morfologie van gespletelip-en-verhemelte-babas aan die spraakterapeut te verskaf, met die doel om die morfo-funksionele verhouding in hierdie babas te bepaal, blyk egter nie geslaagd te wees nie. Op grond van die resultate wat van die proefpersone verkry is, blyk dit nie dat hierdie morfologiese data meer lig op die verhouding met die funksionele aspekte van die baba werp as wat die klassifikasiesisteem wat aangewend is, doen nie. Hierdie tegniek kan egter vir die chirurg tydens beplanning en evaluering van chirurgiese metodes van waarde wees (Marsh \& Gado, 1982).

Die gevolgtrekking word gemaak dat die spraakterapeut wat by die evaluering en behandeling van hierdie babas betrokke is van klassifikasiesisteme gebruik moet maak in die beskrywing van die babas se orofasiale morfologie. Alternatiewe objektiewe evaluasietegnieke soos byvoorbeeld ortodontiese orale afdrukke en die tegniek van kernmagnetiese resonansie moet ook ondersoek word (Berkowitz, 1982).

Ortodontiese orale afdrukke verskaf driedimensionele inligting oor die maksillêre boogvorm en oppervlakte van die palatum (Berkowitz, 1982). Die voordeel van hierdie tegniek is dat dit meer koste-effektief is as gerekenariseerde tomografie en dat alginaatafdrukke van gesplete-lip-en-verhemelte-babas as roetineprosedure by opleidingshospitale gemaak word, wat die toeganklikheid van die tegniek vir die spraakterapeut verhoog (Gavron, 1986).

Die tegniek van kernmagnetiese resonansie moet ook as evaluasietegniek ondersoek word aangesien daar in die vooruitsig gestel word dat hierdie tegniek gerekenariseerde tomografie gaan vervang vanweë die voordele bo dié van tomografie veral ten opsigte van die gebrek aan die gevaar van bestraling (Dickson en Maue-Dickson, 1983).

Ten slotte blyk dit dat die bestudering van die orofasiale morfologie van gesplete-lip-en-verhemelte-babas slegs kan slaag indien interdissiplinêre samewerking voorkom.

\section{- Pedo-oudiometrie}

Die response van die proefpersone op die pedooudiometriese toetsing wat uitgevoer is en die tipe timpanogramme wat deur die proefpersone vertoon is, word in Tabel 5 en 6 verskaf.

Tabel 5: Response van die proefpersone op pedo-oudiometriese toetsing

\begin{tabular}{|l|c|c|}
\hline \multicolumn{1}{|c|}{ Toetsmetode } & Tipe respons & $\begin{array}{c}\text { Persentasic } \\
\text { response }\end{array}$ \\
\hline Vryeveldtoetsing & Positief & $72 \%$ \\
& Negatief & $28 \%$ \\
\cline { 2 - 3 } Elektro-akoestiese & & \\
impedanstoetsing & Teenwoordig & $76 \%$ \\
(Akoestiese refleksdrempel) & Afwesig & $24 \%$ \\
\hline
\end{tabular}

Tabel 6: Timpanometriese resultate wat deur die proefpersone vertoon is

\begin{tabular}{|c|c|l|}
\hline $\begin{array}{c}\text { Tipe } \\
\text { timpanogram }\end{array}$ & $\begin{array}{c}\text { Voorkoms in } \\
\text { persentasie } \\
\text { van getal ore }\end{array}$ & \multicolumn{1}{|c|}{ Interpretasie } \\
\hline A & $38 \%$ & Normaal \\
B & $30 \%$ & Vog in middeloor \\
C & $32 \%$ & Negatiewe druk in middeloor \\
D & $0 \%$ & Littekenweefsel op timpanum \\
E & $0 \%$ & Breuk in ossikulêre ketting \\
\hline
\end{tabular}

Die kriteria wat deur Hodgson (1980) vir die bepaling van middelcorprobleme op grond van pedo-oudiometriese toetsresultate voorgestel is, is aangewend om die voorkoms van middeloorprobleme by die proefpersone te bepaal. Daar is bevind dat $76 \%$ van die proefpersone ten tye van toetsing middeloorprobleme ondervind het.

Tabel 5 dui aan dat $28 \%$ van die proefpersone se reaksie op vryeveldtoetsing (50-70-dB-klankdrukpeil) as negatief geklassifiseer is 
en dat daar by $24 \%$ van die ore wat getoets is geen akoestiese refleksdrempel ontlok kon word nie.

Uitvoering van die twee pedo-oudiometriese toetsmetodes in die eksperimentele prosedure maak 'n vergelyking van die resultate wat so verkry is, moontlik. Proefpersone wie se reaksies op vryeveldtoetsing as negatief gekategoriseer is, het almal op grond van elektro-akoestiese impedanstoetsing middeloorprobleme vertoon. Dit het egter verder geblyk dat $26 \%$ van die proefpersone wie se reaksies op vryeveldtoetsing as positief geklassifiseer is, op grond van resultate wat deur elektro-akoestiese impedanstoetsing verkry is, middeloorprobleme vertoon het. Hierdie bevinding steun literatuurmenings dat elektro-akoestiese impedansoudiometrie middeloorprobleme uitlig selfs al word normale reaksies op vryeveldtoetsing ontlok, en dat dit as 'n sensitiewe meettegniek toegepas kan word in die opsporing van middeloorpatologie by jong kinders (Katz, 1978; Millard, 1980). Die afleiding word gemaak dat vryeveldtoetsing op sigself nie 'n voldoende siftingsprosedure is vir die uitlig van middeloorprobleme by gesplete-lipen-verhemelte-babas nie, ten spyte van die feit dat daar bewys is dat hierdie tegniek lae vals-positiewe resultate in omwattende ondersoeke vertoon het (Katz, 1978). Vryeveldtoetsing in kombinasie met elektro-akoestiese impedanstoetsing blyk volgens die huidige resultate ' $n$ betroubare pedo-oudiometriese siftingsbattery vir babas met gesplete lip en verhemelte te vorm.

- Ontwikkelingskale

Die resultate wat van die proefpersone $(n+25)$ verkry is deur toepassing van die ontwikkelingskale wat in Tabel 3 verskaf is, word kortliks in tabelvorm opgesom. (Sien Tabel 7.)

Tabel 7: Opsommende weergawe van die proefpersone $(n=25)$ se funksionering soos bepaal deur die verskeie ontwikkelingskale

\begin{tabular}{|c|c|c|c|c|c|c|}
\hline Evaluasiemetode & Evaluasieareas & \multicolumn{5}{|c|}{ \% Beoordeling van funksionering } \\
\hline \multirow{7}{*}{$\begin{array}{l}\text { Toepassing } \\
\text { van } \\
\text { ontwikkeling- } \\
\text { skale }\end{array}$} & & \multicolumn{2}{|c|}{ Normaal } & \multicolumn{3}{|c|}{ Agterstand } \\
\hline & & Bogemiddeld & Normaal & Gering & Gemiddeld & Erg \\
\hline & $\begin{array}{l}\text { Kognitiewe } \\
\text { ontwikkeling }\end{array}$ & $4 \%$ & $16 \%$ & $64 \%$ & $12 \%$ & $4 \%$ \\
\hline & $\begin{array}{l}\text { Reseptiewe taal- } \\
\text { ontwikkeling }\end{array}$ & $12 \%$ & $12 \%$ & $64 \%$ & $8 \%$ & $4 \%$ \\
\hline & $\begin{array}{l}\text { Ekspressiewe taal- } \\
\text { ontwikkeling }\end{array}$ & $4 \%$ & $16 \%$ & $60 \%$ & $8 \%$ & $12 \%$ \\
\hline & $\begin{array}{l}\text { Kommunikasie-interaksie- } \\
\text { vermoëns }\end{array}$ & $16 \%$ & $32 \%$ & $36 \%$ & $16 \%$ & $0 \%$ \\
\hline & $\begin{array}{l}\text { Motoriese } \\
\text { ontwikkeling }\end{array}$ & $24 \%$ & $32 \%$ & $24 \%$ & $16 \%$ & $4 \%$ \\
\hline
\end{tabular}

Sleutel: Interpretasie van funksionering:

Normale ontwikkeling: telling op en bokant chronologiese ouderdom

Geringe agterstand: telling $-0,5$ maande onderkant chronologiese ouderdom

Gemiddelde agterstand: telling $-1,0$ maande onderkant chronologiese ouderdom

Erge agterstand: telling -2,0 maande onderkant chronologiese ouderdom

Dit blyk volgens Tabel 7 dat $80 \%$ van die proefpersone 'n agterstand in kognitiewe ontwikkeling toon; 76\% 'n agterstand in taalontwikkeling toon; $62 \%$ 'n kommunikasie-interaksie-agterstand toon en slegs $44 \%$ 'n motoriese ontwikkelingsagterstand toon.

Die relatief hoë insidensie van 'n kognitiewe ontwikkelingsagterstand van die proefpersone bevestig Fox et al. (1978) en McWilliams et al. (1984) se mening dat babas met 'n gesplete lip en verhemelte 'n risiko vertoon om 'n kognitiewe agterstand te ontwikkel.

Opsommend blyk dit dat die swart gesplete-lip-en-verhemelteproefpersone se kognitiewe agterstand aan verskeie faktore toegeskryf kan word. Die orofasiale afwyking wat normale ontwikkeling negatief kan beïnvloed, kulturele gebruike en sosiale omgewings mag as verklaring vir bogenoemde bevindings voorgehou word (Nyiti, 1982; Kolobé, 1984).

Die taalagterstand wat deur die proefpersone vertoon is, word gedeeltelik deur navorsing ondersteun maar ' $n$ presiese verklaring vir die voorkoms van 'n taalagterstand by gesplete-lip-enverhemelte-babas ontbreek tans en verg verdere navorsing (Fox et al. 1978; Long \& Dalston, 1983; Nation \& Wetherbee, 1985).
Die kommunikasie-interaksie-ontwikkelingsagterstand wat deur die proefpersone vertoon is, blyk nie kenmerkend van die'steekproef as geheel en ook nie van 'n ernstige aard te wees nie (Louw, 1986). Dit blyk asof swart gesplete-lip-en-verhemelte-babas dieselfde ontwikkelingsverloop as normale swart babas ten opsigte van kommunikasie-interaksievermoëns vertoon (Strydom, 1985). Tweedens blyk dit asof die gesplete lip en verhemelte nie ' $n$ nadelige invloed op hierdie proefpersone se toetrede tot die kommunikasie-interaksie-situasie uitoefen nie.

Die bevinding dat die swart babas met gesplete lip en verhemelte wat in hierdie steekproef ondersoek is, se motoriese ontwikkeling skynbaar in 'n mindere mate deur hulle orofasiale afwyking beïnvloed is as die motoriese ontwikkeling van blanke gespletelip-en-verhemelte-babas wat in die literatuurbeskryf is (Starr et al. 1977; Fox et al. 1978; Louw \& Van Den Bergh, 1985) kan aan.die hand van ' $n$ tweeledige verklaring geëkspliseer woŕcl.

Dit blyk eerstens dat die voedingsprobleme wat deur die proefpersone ondervind is, nie van so ernstige graad is dat al die proefpersone se motoriese ontwikkeling negatief beïnvloed is nie. Tweedens het verskeie outeurs bewys dat swart babas se vroeë motoriese ontwikkeling in vergelyking met dié van blanke 
Europese en Amerikaanse babas versnel is (Super, 1976; Lester \& Brazelton, 1982; Richter-Strydom \& Griesel, 1984).

Hierdie versnelling in motoriese ontwikkeling word toegeskryf aan kulturele gewoontes ten opsigte van die fisiese hantering van jong swart babas.

Dit blyk dus dat die negatiewe invloed wat 'n gesplete lip en verhemelte op 'n baba se motoriese ontwikkeling kan uitoefen, moontlik by die proefpersone teëgewerk is deur eiesoortige kulturele gebruike en waardes wat vroeë ontwikkeling fasiliteer.

Die evaluering van ' $n$ wye omvang van gedrag wat deur die ontwikkelingskale toegelaat is, het die akkurate bepaling van die vlak van die proefpersone se funksionering moontlik gemaak.

Dit blyk dus op grond van die verkreë resultate dat die vlak van ontwikkeling in grade van normaliteit en agterstand uitgelig kan word wat onder andere toegeskryf word aan die feit dat die proefpersone se relatiewe ontwikkelingsouderdom gebruik is. Dit laat toe vir 'n meer gedetailleerde interpretasie van funksionering. Relatiewe ontwikkelingsouderdom verwys na die ouderdomsvlak wat op die evaluasieskaal behaal is, minus die baba se chronologiese ouderdom. Dit wil sè, die vlak van funksionering relatief tot die individu self word bepaal (Fox et al. 1978).

Die evaluering van funksionering deur middel van die toepassing van ontwikkelingskale blyk dus ' $n$ effektiewe evaluasiemetode te wees en talle riglyne vir behandeling word verskaf.

- Moeder-kind-kommunikasie-interaksie

Direkte observasie is van moeder-kind-interaksies gemaak en kwalitatiewe waarnemings gee aanleiding tot die gevolg- trekking dat geen bewyse bestaan dat die proefpersone se orofasiale afwyking kommunikasie-interaksie met hulle moeders negatief beïnvloed het nie. Hierdie waarneming word toegeskryf aan die feit dat moeders nie die volle implikasie van die afwyking en die behandeling daarvan besef nie. Hulle blyk met die onmiddellike situasie gemoeid te wees eerder as om toekomsgerig te wees (Kolobé 1984).

Die riglyne wat in die ontlokking en waarneming van hierdie interaksies gevolg is, verskaf genoegsame data om ' $n$ verteenwoordigende beeld van individuele moeder-kind-kommunikasie-interaksie daar te stel. Hierdie tipe kwalitatiewe analise pas egter nie voldoende aan by die kwantitatiewe en kwalitatiewe analises wat deur die evaluasiemodel aanbeveel word nie. Verskeie evaluasieskale van moeder-kind-kommunikasie-interaksie wat voorgeskrewe ontlokkingsprosedures aangee en in relatief kort periodes kwantitatiewe en kwalitatiewe data sowel as behandelingsriglyne verskaf, word in die literatuur beskryf (Clezy 1979).

Daar word verder aanbeveel dat video-opnames wel tydens moeder-baba-interaksies aangewend word, aangesien dit tot meer objektiewe optekening van data kan lei. Gebruikmaking van rekenaartegnologie verhoog die objektiwiteit van data-optekening verder en brei die moontlikhede van 'n moeder-kindkommunikasie-interaksie-analise uit (Strydom, 1985).

Dit kom dus voor dat meer tegnologies georiënteerde analises van moeder-kind-kommunikasie-interaksies meer waardevolle inligting verskaf as die subjektiewe waarnemingstegnieke wat benut is.

\section{Voedingsproses}

Die resultate van die beoordeling van die voedingsproses met behulp van die evaluasieprotokol word in Tabel 8 verskaf.

Tabel 8: Resultate van die beoordeling van die voedingsproses

\begin{tabular}{|c|c|c|c|}
\hline $\begin{array}{l}\text { Kategorieë } \\
\text { beoordeel }\end{array}$ & $\begin{array}{l}\text { Getalwaardes } \\
\text { toegeken } \\
i\end{array}$ & Sleutel & $\begin{array}{l}\text { Kenmerke van } \\
\text { proef persone }(n=25) \\
\text { in persentasiewaardes }\end{array}$ \\
\hline Suigrefleks & $\begin{array}{l}1 \\
2 \\
3\end{array}$ & $\begin{array}{l}\text { Sterk suigrefleks (geen suigprobleem) } \\
\text { Aanvanklike sterk' suigrefleks word egter nie } \\
\text { volgehou nie (gemiddelde suigprobleem) } \\
\text { Swak suigrefleks (erge suigprobleem) } \\
\end{array}$ & $\begin{array}{l}32 \% \\
30 \% \\
38 \% \\
\end{array}$ \\
\hline Tipe voedingswyse & $\begin{array}{ll}1 \\
2 \\
3 ! \\
4 ! \\
5\end{array}$ & $\begin{array}{l}\text { Borsvoeding } \\
\text { Bottelvoeding } \\
\text { Voeding met voedingsbeker } \\
\text { Voeding van vloeistowwe met lepel } \\
\text { Buisvoeding }\end{array}$ & $\begin{array}{r}28 \% \\
80 \% \\
26 \% \\
22 \% \\
4 \% \\
\end{array}$ \\
\hline $\begin{array}{l}\text { Tipe voedings- } \\
\text { probleme }\end{array}$ & $\begin{array}{l}1 \\
2 \\
3 \\
3.1 \\
3.2 \\
3.3 \\
\end{array}$ & $\begin{array}{l}\text { Uitermatige las van winde } \\
\text { Oormatige braking } \\
\text { Nasale ontsnapping van vloeistof } \\
\text { Soms } \\
\text { Dikwels } \\
\text { Meestal } \\
\end{array}$ & $\begin{array}{l}22 \% \\
34 \% \\
84 \% \\
29 \% \\
33 \% \\
38 \% \\
\end{array}$ \\
\hline $\begin{array}{l}\text { Graad van voedings- } \\
\text { probleme }\end{array}$ & $\begin{array}{l}1 \\
2 \\
3 \\
\end{array}$ & $\begin{array}{l}\text { Geringe voedingsprobleme } \\
\text { Gemiddelde voedingsprobleme } \\
\text { Ernstige voedingsprobleme }\end{array}$ & $\begin{array}{l}30 \% \\
43 \% \\
27 \% \\
\end{array}$ \\
\hline
\end{tabular}

Daar moet gelet word dat dit vir elke proefpersoon moontlik was om in die kategorieë van tipes voedingsprobleme en tipes voedingswyses meer as een telling te behaal. Dit bring mee dat die persentasiewaardes van die kenmerke van die proefpersone in hierdie twee kolomme dus nie op 'n totaal van $100 \%$ te staan kom nie. Die persentasie verwys telkens na die getal proefpersone uit 25 wat 'n sekere kenmerk vertoon. 
Die drie aspekte van die voedingsproses wat geëvalueer is, toon 'n noue verwantskap en kan dus nie onafhanklik geèvalueer word indien ' $n$ ware beeld van die gesplete-lip-en-verhemelte-babas se voedingsprobleme verkry moet word nie. Die graad van die voedingsprobleem wat op hierdie resultate bereken is, word gevolglik as 'n akkurate beoordeling van die probleem beskou.

Volgens Tabel 8 het 30\% van die proefpersone geringe en $70 \%$ gemiddelde $(43 \%)$ tot erge $(27 \%)$ voedingsprobleme ondervind. Die feit dat $30 \%$ van die proefpersone slegs 'n geringe voedingsprobleem getoon het, word bevestig deur die resultate dat $32 \%$ van die proefpersone 'n sterk suigrefleks vertoon het en dat bottelen borsvoeding die voedingswyse was wat die algemeenste toegepas is.

Die feit dat slegs $38 \%$ van die proefpersone suigprobleme gehad het, dui daarop dat aanpassingsgedrag tydens die voedingsproses moontlik vir hierdie verskynsel verantwoordelik gehou kan word. Kliniese waarnemings tydens die empiriese ondersoek dui daarop dat aanpassingsgedrag in die vorm van aanpassings in die plasing en bewegings van die orale strukture, veral van die tong, tydens vloeistofinname voorgekom het. Hierdie aanpassingsgedrag kan egter nie sonder die aanwending van objektiewe meettegnieke, soos byvoorbeeld kineradiografie, akkuraat beskryf word nie. Kennis van aanpassing en kompensatoriese bewegings word as belangrik beskou aangesien dit ' $n$ invloed op die individu se orale sensories-motoriese ondervinding uitoefen wat ' $n$ rol in latere spraakproduksiepatrone kan speel (Fletcher, 1978). Die gebrek aan toepassing van objektiewe meettegnieke impliseer dat moontlike belangrike aspekte van die suigaksie oor die hoof gesien kan word.

Evaluering van die voedingsproses dek nie wanvoeding nie en aangesien swart onwikkelende gemeenskappe se babas dikwels wangevoed is (Morley, 1979) word aanbeveel dat inligting aangaande voedingstatus van die mediese personeel verkry word.

\section{Spektrografiese analise van huilbuie}

Sewe huilkenmerke is deur middel van huilbuie van die proefpersone bestudeer. Aangesien geen metings van die huilkenmerke van melodietipe en nasaliteit gemaak kon word nie, is hierdie kenmerke slegs kwalitatief bespreek. Die data van die vyf oorblywende huilkenmerke is statisties verwerk en word in Tabel 9 verskaf.

Tabel 9: Data wat van spektrografiese huilanalises van die proefpersone verkry is $(n=25)$

\begin{tabular}{|l|l|l|c|c|}
\hline \multirow{2}{*}{ HUILKENMERKE } & \multicolumn{3}{|c|}{ STATIESTIESE BEREKENINGE } \\
\cline { 2 - 5 } & $\begin{array}{l}\text { Rekenkundige } \\
\text { gemiddeld }\end{array}$ & $\begin{array}{l}\text { Standaard- } \\
\text { afwyking }\end{array}$ & Mediaan & Variasiewydte \\
\hline $\begin{array}{l}\text { Latente periode } \\
\text { (sekondes) }\end{array}$ & 1,69 sek & 0,95 sek & 1,60 sek & 3,40 sek \\
\hline $\begin{array}{l}\text { Duur van huilbuie } \\
\text { (sekondes) }\end{array}$ & $2,38 \mathrm{sek}$ & $1,63 \mathrm{sek}$ & $2,00 \mathrm{sek}$ & $5,60 \mathrm{sek}$ \\
\hline $\begin{array}{l}\text { Amplitude van huilsein } \\
\text { (dB) }\end{array}$ & $75,17 \mathrm{~dB}$ & $2,89 \mathrm{~dB}$ & $74,52 \mathrm{~dB}$ & $10,30 \mathrm{~dB}$ \\
\hline $\begin{array}{l}\text { Minimum toonhoogte van } \\
\text { fundamentele frekwensie } \\
\text { (Hz) }\end{array}$ & $449,2 \mathrm{~Hz}$ & $120,8 \mathrm{~Hz}$ & $410,0 \mathrm{~Hz}$ & $550,0 \mathrm{~Hz}$ \\
\hline $\begin{array}{l}\text { Maksimum toonhoogte van } \\
\text { fundamentele frekwensie } \\
\text { (Hz) }\end{array}$ & $813,4 \mathrm{~Hz}$ & $293,9 \mathrm{~Hz}$ & $670,0 \mathrm{~Hz}$ & $1060,0 \mathrm{~Hz}$ \\
\hline
\end{tabular}

Opsommend blyk dit dat die proefpersone as groep nie beduidend verskil het van die literatuurbeskrywings van die sewe huilkenmerke van normale babas nie (Golub \& Corwin, 1982; Lester, 1984). Op grond van hierdie resultate is die gevolgtrekking gemaak dat ' $n$ anatomiese afwyking van die orofasiale strukture nie ' $n$ beduidende invloed op die huilpatrone van babas uitoefen nie.

Hierdie resultate bevestig die bevinding van Michelsson et al. (1975) wat die enigste bekende huilanalise op gesplete-lip-enverhemelte-babas uitgevoer het. Bogenoemde afleidings is egter in direkte teenstelling met die mening van Golub \& Corwin (1982) naamlik dat enige afwyking van die anatomiese strukture wat by die produksie van huilgedrag betrokke is, in die akoestiese eienskappe van die huilbuie gereflekteer sal word. Indien 'n . gesplete lip en verhemelte ' $n$ invloed op ' $n$ baba se huilpatroon uitoefen, is dit van so 'n geringe aard dat dit nie deur 'n spektrografiese analise bewys kan word nie.

Ten slotte blyk dit dat die evaluasietegniek van huilanalise 'n definitiewe rol te vervul het in die evaluering van die funksionering van die sentrale senuweestelsel in jong babas, maar weinig inligting verskaf oor die invloed wat 'n gesplete lip en verhemelte op huilgedrag as voorloper van latere spraakproduksie uitoefen.

Verdere ontwikkeling van die tegniek van huilanalise kan leitot 'n beter begrip van huilgedrag as ' $n$ weerspieëling van die fisiologiese meganismes en anatomiese strukture van die baba se klankproduksiesisteem. Sulke inligting sal insig gee in die wyse waarop babas die betrokke spierstelsels koördineer en kontroleer en sal sodoende nuwe lig op prelinguistiese gedrag werp.

\section{Fonetiese analise van vokaliseringsgedrag}

Op grond van die fonetiese analise wat van die proefpersone se vokaliseringsgedrag gemaak is, is bevind dat glottale artikulasie die meeste gebruik is tydens konsonantproduksies. (Sien Tabel 10.) Tydens die normale ontwikkelingsverloop is daar egter ' $n$ afname in glottale konsonante na die ouderdom van twee maande en dit kom dus voor dat die gesplete-lip-en-verhemelte-proefpersone kwalitatief van die normale ontwikkelingsverloop verskil. Die palatale plek van artikulasie is in $18,7 \%$ van die konsonantproduksies gebruik volgens Tabel 10. Dit kom voor asof die proefpersone se gesplete verhemelte nie 'n beduidende 
invloed op palatale artikulasie uitgeoefen het nie. Verder is die proefpersone se vokaliseringsgedrag gekenmerk deur die relatief hö̈ voorkoms van frikatiewe $(38,3 \%)$ en nasale $(32,3 \%)$ klanke. Die hoë voorkoms van frikatiewe is 'n kenmerk van vroeë normale ontwikkeling en die afleiding word gemaak dat die proefpersone 'n geringe ontwikkelingsagterstand vertoon (Mowrer, (1980). Eksplosiewe klanke is gekenmerk deur glottale klanke veral die glottale afsluitingsklank $/ ? \%$.

Tabel 10: Opsomming van die prelinguistiese konsonantproduksies van die proefpersone $(n=25)$

\begin{tabular}{|c|c|c|c|c|c|c|c|}
\hline \multirow[b]{2}{*}{$\%$ produksies } & \multicolumn{7}{|c|}{ PLEK VAN ARTIKULASIE } \\
\hline & Bilabiaal & $\begin{array}{c}\text { Labio- } \\
\text { biaal }\end{array}$ & $\begin{array}{l}\text { Inter- } \\
\text { dentaal }\end{array}$ & $\begin{array}{l}\text { Alveo- } \\
\text { lêr }\end{array}$ & $\begin{array}{c}\text { Pala- } \\
\text { taal }\end{array}$ & Velêr & Glottaal \\
\hline & $15,2 \%$ & $2,2 \%$ & $7,5 \%$ & $13,2 \%$ & $18,7 \%$ & $12,4 \%$ & $30,8 \%$ \\
\hline & \multicolumn{7}{|c|}{ WYSE VAN ARTIKULASIE } \\
\hline & $\begin{array}{l}\text { Eksplo- } \\
\text { siewe }\end{array}$ & $\begin{array}{l}\text { Frika- } \\
\text { tiewe }\end{array}$ & Nasale & $\begin{array}{c}\text { Wrywing- } \\
\text { lose kon- } \\
\text { tinuante } \\
\end{array}$ & $\begin{array}{c}\text { Late- } \\
\text { rale } \\
\text { klanke }\end{array}$ & $\begin{array}{l}\text { Gly- } \\
\text { klanke }\end{array}$ & Trillers \\
\hline & $20,5 \%$ & $38,3 \%$ & $32,3 \%$ & $7,3 \%$ & $0 \%$ & $0 \%$ & $1,6 \%$ \\
\hline
\end{tabular}

Tabel 11 verskaf 'n oorsig van die proefpersone se vokaalproduksies en hiervolgens blyk dit dat die plek van vokaalproduksie oreenstem met die van normale ontwikkeling. Verder toon Tabel 11 dat $73,42 \%$ van die vokale in 'n middellaag-toonhoogteposisie geproduseer is, wat dui op vertraagde ontwikkeling en ooreenstem met die bevindinge van O'Gara en Logemann, 1983.

Tabel 11: Voorkoms van die vokale wat geproduseer is volgens plek van artikulasie en tonghoogte tydens produksie

\begin{tabular}{|l|c|c|c|}
\hline $\begin{array}{l}\text { Tonghoogte } \\
\text { tydens } \\
\text { produksie }\end{array}$ & $\begin{array}{c}\% \text { Vokale } \\
\text { geproduseer }\end{array}$ & $\begin{array}{c}\text { Plek van } \\
\text { artikulasie }\end{array}$ & $\begin{array}{c}\% \text { Vokale } \\
\text { geproduseer }\end{array}$ \\
\hline Hoog & $8,63 \%$ & Voor & $40,85 \%$ \\
\hline Middel & $73,42 \%$ & Middel & $41,88 \%$ \\
\hline Laag & $17,95 \%$ & Agter & $17,27 \%$ \\
\hline
\end{tabular}

Die gevolgtrekking is bereik 'dat beide die konsonant- en vokaalproduksies van die gesplete-lip-en-verhemelte-proefpersone kwalitatief verskil van die literatuurbeskrywings van die vokaliseringsgedrag van normale babas (Mowrer, 1980; O'Gara \& Logemann, 1983).

Fonetiese analise laat slegs toe vir 'n kwantitatiewe en kwalitatiewe beskrywing van konsonant- en vokaalproduksies en daar word aanbeveel dat vokalisering ook uit 'n sosialiseringsperspektief bestudeer moet word (Smith \& Oller, 1981). Die verwantskap tussen die motoriese komponente van prelinguistiese vokaliserings- en spraakgedrag moet bepaal word om meer spesifieke riglyne vir vroeë behandelingsprogramme te verskaf (Sheppard, 1980). Die invloed van tydsberekening van chirurgie, en die dra van ' $n$ maksillêre prostese moet ook bestudeer word. Dit blyk dus dat om 'n meer verteenwoordigende beeld van vokaliseringsgedrag as deel van prelinguistiese kommunikasiegedrag te verkry, die evaluering van vokaliseringsgedrag vanuit 'n breër perspektief beskou moet word as wat deur die evaluasiemodel voorgestel is.

Op grond van die voorafgaande resultate is statistiese berekeninge uitgevoer om te bepaal watter verwantskappe tussen die vroeë morfologiese en funksionele ontwikkeling van die proefpersone bestaan. Die doel van hierdie bewerking is om op grond van verkreë resultate die holistiese evaluasiemodel te evalueer.
Eerstens is sewe-en-twintig korrelasies wat tussen die evaluasieareas bestaan, bereken (Louw, 1986). Daar is bevind dat 52\% van die korrelasies 'n statisties beduidende verwantskap toon wat bevestig dat die vroeë ontwikkeling van die proefpersone wel sinergisties van aard is en 'n simbiotiese interaksie, vertoon. Die afleiding word gemaak dat die holistiese evaluasiemodel voorsiening maak vir die noue interaksie van vroeë ontwikkeling en dat die geselekteerde evaluasietegniek mekaar aanvul eerder as oorvleuel. Die holistiese evaluasiemodel maak dus voorsiening vir 'n diepte-evaluasie van die verreikende negatiewe invloed wat 'n gesplete lip en verhemelte op die baba kan uitoefen.

Tweedens is die statistiese ontledingstegniek van stapsgewyse meervoudige lineêre regressie (Draper \& Smith, 1981) toegepas om te bepaal watter ontwikkelingsaspekte van die holistiese evaluasiemodel as voorspellers vir funksionering in sekere evaluasieareas dien. Resultate dui daarop dat dit statisties bewys is dat taalontwikkeling, kommunikasie-interaksievermoèns, voedings probleme, kognitiewe ontwikkeling en graad van die tipe spleet belangrike voorspellers van die verskillende evaluasieareas is (Louw, 1986). Die ontwikkelingsaspekte wat deur die holistiese evaluasiemodel gedek word, blyk oor die algemeen 'n goeie seleksie te wees aangesien daar bewys is dat 'n noue verwantskap tussen die ontwikkelingsaspekte bestaan en dat sekere van hierdie aspekte van ontwikkeling as voorspellers van ander ontwikkelingsaspekte kan funksioneer.

Die voorspellende aard van die verskillende ontwikkelingsaspekte moet egter met omsigtigheid geïnterpreteer word. Hierdie bevinding impliseer slegs dat die ontwikkelingsaspekte sinergisties van aard is, en nie dat daar byvoorbeeld in die kliniese praktyk slegs een ontwikkelingsaspek geëvalueer hoef te word nie met die veronderstelling dat afleidings oor ander ontwikkelingsaspekte op grond van die geëvalueerde area se voorspellingswaarde gemaak kan word nie. Die voorspellers dien eerder as 'n verklaring van funksionering in ' $n$ betrokke evaluasiearea.

Op grond van die bogenoemde bevindings dat toepaslike evaluasieareas deur die holistiese evaluasiemodel gedek word, kan die afleiding gemaak word dat die evaluasietegnieke wat aangewend is, toepaslike inligting aangaande die proefpersone se funksionering verskaf het wat hulle geskiktheid as effektiewe tegnieke onderskraag.

Die kliniese toepassing van die holistiese evaluasiemodel het dus genoegsame inligting verskaf om beide evaluasieareas en die 
evaluasietegnieke van die model krities te evalueer en aanbevelings oor die aanwending van die tegnieke te maak.

\section{GEVOLGTREKKINGS}

$\mathrm{Na}$ aanleiding van die voorafgaande bespreking van die resultate wat deur toepassing van die holistiese evaluasiemodel verkry is, blyk dit dat noukeurige teoretiese seleksie van evaluasiemetodes en meetinstrumente alleen nie voldoende is om die kliniese uitvoerbaarheid en bruikbaarheid te bepaal nie. Dit het duidelik uit die resultate geblyk dat kliniese toepassing ook krities geëvalueer moet word alvorens evaluasiemetodes en meetinstrumente sinvol beoordeel kan word.

Daar word aanbeveel dat evaluasiemetodes en meetinstrumente beide op grond van teoretiese en kliniese oordeel geselekteer word. Verskeie leidrade ten opsigte van die seleksie van gepubliseerde meetinstrumente wat van toepassing is op babas (McLean \& McLean, 1978; Lund \& Duchan, 1983) en wat met vrug benut kan word, is in die literatuur beskikbaar. Indien die spraakterapeut egter 'n nuwe evaluasiemetode of meettegniek wil aanwend wat nog nie van te vore in die literatuur beskryf of geëvalueer is nie, word onderwerping aan 'n praktiese toets aanbeveel. Op grond van verkreë resultate van so 'n praktiese toets moet ' $n$ beoordeling van die volgende aspekte uitgevoer word: betroubaarheid; geldigheid; koste; tyd wat nodig is vir die uitvoering sowel as vir die verwerking van resultate; gemak van uitvoering; beskikbaarheid van evaluasiemetodes en aanpasbaarheid daarvan by 'n gegewe populasie.

'n Krities evaluerende benadering tot die beplanning en uitvoering van die vroeë evaluasie van babas behoort tot verantwoordbare en praktiese optrede deur die spraakterapeut te lei.

In die bespreking van die resultate is daar gewys op die moontlike toepassingsmoontlikhede van die evaluasiemetodes en meetinstrumente in terme van navorsing. Aangesien die evaluasiemodel primêr vir navorsingsdoeleindes ontwikkel is en baie tydrowend is, word aanbeveel dat die evaluasieproses tydens kliniese dienslewering sinvol verkort word.

Evaluering van swart babas met gesplete lip en verhemelte word weer eens as praktiese voorbeeld voorgehou. Hiervolgens word voorstelle ten opsigte van elke evaluasiearea van die evaluasiemodel aan die hand gedoen om te illustreer hoe die uitgangspunt van die navorsingsgerigte evaluasiemodel behou is terwyl die kliniese uitvoering verkort en vergemaklik word.

- Orofasiale morfologie: Verkryging van inligting oor die klassifikasie van die tipe gesplete lip en verhemelte en bykomstige belangrike morfologiese inligting van die chirurg.

- Gehoorvermoëns: Siftingstoetsing soos in die evaluasiemodel voorgestel is.

- Kognitiewe ontwikkeling: Toepassing van die Bayley Scales of Infant Development - Mental Scale (Bayley), 1969) en gebruikmaking van die voorlopige norme van swart babas opgestel deur Richter en Griesel (1985).

Die verandering word voorgestel op grond van Richter-Strydom en Griesel (1984) se suksesvolle toepassing van hierdie ontwikkelingskaal op normale swart babas en die feit dat hulle voorlopige norme vir kognitiewe ontwikkeling van swart babas opgestel het.

- Huilanalise: Toepassing slegs indien daar vermoed word dat die baba ' $n$ af wyking van die sentrale senuweestelsel vertoon.

- Voedingsproses: Evaluering deur objektiewe waarneming soos in die holistiese evaluasiemodel voorgeskryf is.
- Vokaliseringsgedrag: Ontlok tydens moeder-kind-kommunikasie-interaksie en slegs tipe klanke wat geproduseer word, word genoteer.

- Reseptiewe en ekspressiewe taalontwikkeling: Toepassing van die Denver Developmental Screening Test (Frankenburg \& Dodds, 1969) en gebruikmaking van voorlopige norme opgestel deur Richter en Griesel (1985).

- Kommunikasie-interaksie-ontwikkeling: Evalueer tydens moeder-kind-kommunikasie-interaksie.

- Moeder-kind-interaksie: Ontlok tien minute interaksie tussen moeder en baba en beskryf breedweg moeder-kindinteraksie-patrone, die baba se interaksionele en vokaliseringsgedrag. Gebruik riglyne wat in holistiese evaluasiemodel verskaf word (Louw, 1986).

- Motoriese ontwikkeling: Toepassing van Denver Developmental Screening Test (Frankenburg \& Dodds, 1969) en gebruik voorlopige norme wat deur Richter en Griesel (1985) vir swart babas opgestel is.

- Interpretasie van data moet egter steeds volgens die riglyne wat in die evaluasiemodel verskaf word, geskied (Louw, 1986).

'n Ernstige probleem wat egter in die kliniese praktyk voorkom, is naamlik dat beskikbare hulpbronne nie voldoen aan die vereistes wat gestel word om die behoeftes van die gemeenskap aan mediese en paramediese dienste te bevredig nie.

Die konsep van mede-konsultasie wat deur Uys (1985) voorgestel is, kan met groot vrug in die evaluering van swart babas met gesplete lip en verhemelte angewend word. Volgens die uitgangspunt van die medekonsultasiemodel kan die verpleegkundige as sorgpersoon benut word aangesien die rol van die verpleegster toenemend uitbrei (Foster \& Anderson, 1978; Morley, 1979; Uys, 1985). Die verpleegkundige se rol as sorgpersoon kan die volgende omsluit:

- Uitvoering van gehoor- en ontwikkelingsiftingsprogramme by swart gesplete-lip-en-verhemelte-babas in roetine babaklinieke, tydens hospitalisering van die babas en by crèches;

- Verskaffing van individuele vroeë stimulasieprogramme en lesings oor die belang van vroeë stimulasie aan groepe ouers van gesplete-lip-en-verhemelte-kinders.

Ten slotte blyk dit dat die kritiese evaluering van evaluasietegnieke op grond van empiriese bewyse wat deur kliniese toepassing verkry is, die geskiktheid, waarde en bruikbaarheid,van die evaluasietegnieke verhoog en verskillende toepassingsmoontlikhede daarstel.

\section{BEDANKING}

Die skrywers erken met dank die finansiële ondersteuning van die Raad van Geesteswetenskaplike Navorsing.

\section{VERWYSINGS}

Anderson, D., Nelson J. en Fowler S. "Development Assessment schema" in Northcott, W.H. (red.): Curriculum guide: Hearing impaired children (0-3 years) and their parents. Washington D.C.: The Alexander Graham Bell Association for the Deaf, Inc. 1978.

Bangs, T.E. en S. Dodson. Birth to three developmental scale. New York: Teaching Resources. 1979.

Banna, M. "Basic introduction to computerized tomography" in Joumal of the Canadian Association of Radiologists, 27, pp. 143148, 1976.

Bayley, N. Manual for the Bayley Scales of infant development. New York: The Psychological Corporation, 1969. 
Berkowitz, S. "Some questions, a few amswers in maxillo-mandibular surgery. The role of muscle and growth" in Clinical Plastic Surgery, 9, pp. 603-633, 1982.

Berling, A.J.: "Classification of cleft lip and palate and related craniofacial disorders" in Bzoch, K.R. (red.): Communicative disorders related to cleft lip and palate (2de uitgawe). Boston: Little, Brown, 1979.

Bower, T.G.R. Development in infancy (2de uitgawe). San Francisco: Freeman, 1982.

Bzoch, K.R. en League, R. Assessing language skills in infancy. Baltimore: University Park Press, 1971.

Clezy, G. Modification of the mother-child interchange in language, speech and hearing. London: Edward Arnold, 1979.

Crystal, D. "Linguistic mythology and the first year of life" in British Journal of Disorders of Communication, 32, pp. 29-36, 1973.

Dickson, D.R. en Maue-Dickson, W. "Tomographic assessment of craniofacial structures: Cleft lip/palate" in Cleft Palate Journal, 20, pp. 23-34, 1983.

Draper, N.R. en Smith, H. Applied regression analysis (2e uitgawe). New York: John Wiley, 1981.

$\mathrm{Du}$ Bose-Fewell, R. Nonverbal indicators of communicative exchange (Hersiene uitgawe). Persoonlike Kommunikasie: Hoof: Child Development and Mental Retardation Center, Experimental Education Unit, University of Washington, 1982.

Dunst, C.J. "A cognitive-social approach for assessment of early nonverbal communicative behaviour" in JCCD. 2 , pp. 110-123, 1978.

Emerick, L.L. en Haynes, W.O. Diagnosis and Evaluation in Speech Pathology. (3e uitgawe) New Jersey: Prentice-Hall Inc. 1986.

Fletcher, S.G. "Maturation of the speech mechanism" in Folia Phoniatrica, 25, pp. 161-172, 1973.

Foster, G.M. en Anderson, B.G. Medical anthropology. Ne York: John Wiley, 1978.

Fox, D.R., Lynch, J.I. en Brookshire, B.L. "Selected developmental factors of cleft palate children between two and thirty-three months of age" in Cleft Palate Journal, 15, pp 239-245, 1978.

Frankenburg, W.K. en Dodds, J.B. Denver developmental screening test. Denver: LADOCA Publishing Foundation.

Gavron, G. Persoonlike kommunikasie, Departement Ortodonsie, Universiteit van die Witwatersrand, 1986.

Golub, H.L. en Corwin, M.J. "Infant cry: A clue to diagnosis" in Pediatrics, 69 (2), pp. 197-201, 1982.

Hodgson, W.R. Basic audiologic evaluation. Baltimore: Williams and Wilkins, 1980.

Katz, J. (red.) Handbook of clinical audiology (2e uitgawe). Baltimore: Williams en Wilkins, 1978.

Kaye, K. "Thickening thin data: The maternal role in developing communication and language" in Bullowa, M. (red.): Before Speech. The beginning of interpersonal communication. New York: Cambridge University Press, 1979.

Kolobé, T. Persoonlike kommunikasie. Senior Lektrise, Departement Fisioterapie, MEDUNSA, 1984.

Lester, B.M. "A biosocial model of infant crying" in Lipsitt, L.P. en Rovee-Collier, C. (reds.): Advances in infancy research, volume 3. *S.pl., New Jersey: Ablex Publishing,' 1984.

Lester, B.M. en Brazelton, T.B. "Cross cultural assessment of neonatal behaviour" in Wagner, D.A. en Stevenson, H.W. (reds.): Cultural perspectives on child development. San Francisco: Freeman, 1982.

Liebergott, J. Bashir, A.S. en Schultz, M.C. "Dancing around and making strange noises: Children at risk" in Holland, A.L. (red.): Language disorders in children. Recent advances. San Diego: College-Hill Press, 1984.
Long, N.V. en Dalston, R.M. "Comprehension abilities of oneyear-old infants with cleft lip and palate" in Cleft Palate Journal, 20, pp. 303-306, 1983.

Louw, B. "Improving the efficacy of speech and language pathology: The implications of similarities and differences as manifested in communicative disorders in a multiracial, multilingual society" in The Proceedings of the 18th Congress of the International Association of Logopaedics and Phoniatrics, 2, pp. 49-55. Washington, D.C. 1980.

Louw, B. Swart babas met gesplete lip en verhemelte: 'n Morfofunksionele studie. Ongepubliseerde D.Phil-verhandeling. Universiteit van Pretoria, 1986.

Louw, B. en van den Berg, C. "Vroeè ingryping by jong kinders met gesplete lip en verhemelte: Riglyne vir evaluasie en behandeling". Referaat: Kongres van die Suid-Afrikaanse Vereniging vir Spraak en Gehoorheelkunde. Johannesburg, Julie 1985.

Marge, M. "The prevention of communication disorders" in ASHA, 26 (8), pp. 29-33, 1984.

Marsh, J.L. en Gado, M. "Surgical anatomy of craniofacial dysostoses: Insights from CT scans" in Cleft Palate Journal, 19, pp. 212-221, 1982.

Maue-Dickson, W. en Dickson, D.R. "Anatomy and physiology related to cleft palate: Current research and clinical implications" in Plastic and Reconstructive Surgery, 65, pp. 83-90, 1980.

McClowry, D.P. "Strategies for evaluating communication development in infants" in Seminars in Speech, Language \& Hearing. 3, pp. 45-51, 1982.

McLean J. en McLean, L. A transactional approach to early language training. Columbus, Ohio: Merrill, 1978.

McWilliams, B.J., Morris, H.L. en Shelton, R.L. Cleft palate speech. St Louis: Mosby, 1984.

Michelsson, K., Raes, J., Thoden, C. en Wasz-Höckert, O. "Sound spectrographic cry analysis in neonatal diagnostics. An evaluative study" in Journal of Phonetics, 10, pp. 79-88, 1982.

Michelsson, K., Sirviö, P., Koivisto, M., Sovijärvi, A. en WaszHöckert, O. "Spectrographic analysis of pain cry in neonates with cleft palate" in Biologica Neonate, 26, pp. 353-358, 1975.

Millard, D.R. Cleft craft: The evaluation of its surgery, III Alveolar and palatal deformities. Boston: Little, Brown, 1980.

Morley, D. Paediatric priorities in the developing world. London: Butterworths, 1979.

Mowrer, D.E. "Phonological development during the first year of life" in Lass, N.J. (red.): Speech and language: Advances in basic research and practice, volume 4. New York: Academic Press, 1980.

Munro, I.R. "Principles of craniofacial surgery" in Converse, J.M. (red.): Reconstructive plastic surgery, volume 4: Cleft lip and palate. Cranofacial deformities (2e uitgawe). Philadelphia: Saunders, 1977.

Nation, J.E., Wetherbee, M.A. "Cognitive-communicative development of identical triplets, one with unilateral cleft lip and palate" in Cleft Palate Journal, 22, pp. 38-49, 1985.

Nyiti, R.M. "The validity of "cultural differences explanations" for cross-cultural variation in the rate of Piagetian cognitive development" in Wagner, D.A. \& Stevenson, H.W. (reds.): Cultural perspectives on child development. San Francisco: Freeman, 1982.

O'Gara, M.M. en Logemann, J.A. Early infant vocalizations in the presence of palatial insufficiency. Referaat: ASHA Nation Conference, 1983.

Prescott, R. "Infant cry sound: Developmental features" in Journal of the Acoustic Society of America, 57, pp. 1186-1191, 1980 . 
Richter, L.M. en Griesel, R.D. The performance of young African children (2 to 12 months) on the: 1. Bayley Scales of infant development; 2. Denver Developmental Screening Test. Preliminary analysis: Instituut vir Gedragswetenskappe, Universiteit van Suid-Afrika. Pretoria: Universiteit van SuidAfrika, 1985.

Richter-Strydom, L.M. en Griesel, R.D. African infant precocity: $A$ study of a group of South African infants from two to fifteen months of age. Departementele navorsing: Instituut vir Gedragswetenskappe, Universiteit van Suid-Afrika. Pretoria: Universiteit van Suid-Afrika, 1984.

Schepers, J.M. The assessment of brain damage from a psycho metric point of view. Forensic Science, 1, 269-311, 1972.

Seibert, J.M. en Hogan, A.E.: "A model for assessing social and object skills and planning intervention" in McClowry, D.P., Guildord, A.M. \& Richardson, S.O. (reds.): Infant communication development, assessment, and intervention. New York: Grune \& Stratton, 1983.

Sheppard, J.J. "Motor components of social vocalizations in infants" pp. 126-130 in The Proceedings of the 18th Congress
Smith, B.L. \& Oller, D.K. "A comparative study of premeaningful vocalizations produced by normally developing and Downs syndrome infants" in Journal of Speech and Hearing Disorders, 46, pp. 46-51, 1981.

Starr, P., Chinsky, R., Canter, H. en Meier, J. "Mental, motor and social behaviour of infants with cleft lip and/or palate" in Cleft Palate Journal, 14, pp. 140-147, 1977.

Strydom, L.M. Development of communication between African mothers and their infants in the first year of life. Referaat: Biennial Meeting of the Society for Research and Child Development, Toronto, April 1985.

Super, C.M. "Environmental effects on motor development: The case of African infant precocity" in Developmental Medicine and Child Neurology, 18, pp. 561-567, 1976.

Trevarthen, C. "Communication and cooperation in early infancy: A description of primary intersubjectivity" in Bullowa, M. (red.); Before speech: The beginning of interpersonal communication. Cambridge: Cambridge University Press, 1979.

Uys, I.C. "'n Medekonsultasiemodel vir spraak-- en gehoorterapie in die RSA" in Hay, I.S. \& Uys, I.C. (reds.): Taal- 